\title{
Design of Metamorphic Dual-Junction InGaP/GaAs Solar Cell on Si with Efficiency Greater than 29\% using Finite Element Analysis
}

\author{
Nikhil Jain, and Mantu K. Hudait \\ Virginia Tech, Blacksburg, VA, 24061, USA
}

\begin{abstract}
Heterogeneous integration of multijunction III-V solar cells on $\mathrm{Si}$ is a promising solution for the widespread commercialization of III-V cells. However, the polar on non-polar epitaxy and $4 \%$ lattice-mismatch between $\mathrm{GaAs}$ and $\mathrm{Si}$ results in formation of defects and dislocations, which can significantly impede the minority carrier lifetime and hence the cell performance. We have investigated the impact of threading dislocation density on the performance of dual-junction (2J) $n+/ p$ InGaP/GaAs solar cells on $\mathrm{Si}$. Using our calibrated model, the metamorphic $2 \mathrm{~J}$ cell on $\mathrm{Si}$ was optimized by tailoring the $2 \mathrm{~J}$ cell design on $\mathrm{Si}$ to achieve current-matching between the subcells at a realistic threading dislocation density of $10^{6} \mathrm{~cm}^{-2}$. We present a novel $2 \mathrm{~J}$ InGaP/GaAs cell design on $\mathrm{Si}$ at a threading dislocation density of $10^{6} \mathrm{~cm}^{-2}$ which exhibited a theoretical conversion efficiency of greater than $29 \%$ at AM1.5G spectrum, indicating a path for viable III-V multijunction cell technology on Si.
\end{abstract}

Index Terms - III-V semiconductor materials, charge carrier lifetime, epitaxial layers, photovoltaic cells, semiconductor device modeling, short circuit currents, silicon.

\section{INTRODUCTION}

III-V multijunction solar cells have been the primarily candidate for space satellites. However, the use of III-V cells for terrestrial applications is currently limited by the size and cost of Ge and III-V substrates. Heterogeneous integration of such III-V cells on large diameter and cheaper Si substrate can not only substantially lower the cost of III-V cells, but also increase their yield per die. Furthermore, implementation of III-V solar cells on $\mathrm{Si}$ in conjunction with substrate re-use technologies [1], [2] can lead to additional cost reduction. However, viability of III-V InGaP/GaAs solar cells on $\mathrm{Si}$ relies on the ability to grow high quality GaAs on $\mathrm{Si}$ with careful lattice engineering and substrate treatment. The polar on non-polar epitaxy and the 4\% lattice-mismatch between $\mathrm{GaAs}$ and $\mathrm{Si}$ may results in formation of various defects including dislocations. These dislocations can propagate into the photoactive cell region, significantly impeding the minority carrier lifetime and hence the overall cell performance. Therefore, it becomes extremely important to correlate the impact of dislocation density on the performance of metamorphic III-V tandem solar cells on $\mathrm{Si}$.

The focus of this paper is to provide a systematic study on the correlation of threading dislocation density (TDD) and minority carrier lifetime on the photovoltaic performance of $2 \mathrm{~J}$ $\mathrm{InGaP} / \mathrm{GaAs}$ solar cell on $\mathrm{Si}$. The schematic of the structure investigated in this paper is shown in Fig. 1. As a starting point, the base thicknesses in the GaAs and InGaP cell were set to be $2.5 \mu \mathrm{m}$ and $0.9 \mu \mathrm{m}$, respectively [3]. We then optimized the $2 \mathrm{~J} \mathrm{n}+/ \mathrm{p} \mathrm{InGaP} / \mathrm{GaAs}$ cell design on $\mathrm{Si}$ by achieving current-matching condition between the subcells at a TDD of $10^{6} \mathrm{~cm}^{-2}$. The results from our work provide a quantitative assessment of the solar cell figure-of-merits as a function of TDD, thus enabling more efficient cell design and prediction of the metamorphic $2 \mathrm{~J} \mathrm{InGaP} / \mathrm{GaAs}$ cell performance on Si.

The impact of TDD on cell performance has been previously investigated [4]-[9], however, their analysis was limited to $1 \mathrm{~J} \mathrm{GaAs}$ cell on $\mathrm{Si}$. $\mathrm{J}_{\mathrm{sc}}$ used for modeling the impact of TDD on $\mathrm{V}_{\mathrm{oc}}$ was assumed to be independent of TDD [8]. However, in reality $\mathrm{J}_{\mathrm{sc}}$ decreases with increase in TDD and may have a significant impact on the cell efficiency. There has not been significant work done on the modeling-assisted design of metamorphic tandem cells incorporating the impact of TDD. This paper provides the first study on modeling \& optimization of metamorphic $2 \mathrm{~J} \mathrm{n}+/ \mathrm{p} \mathrm{InGaP} / \mathrm{GaAs}$ cell design on $\mathrm{Si}$ at $\mathrm{AM} 1.5 \mathrm{G}$ spectrum using finite element analysis without assuming a constant $\mathrm{J}_{\mathrm{sc}}$.

\section{SIMULATION MODEL}

Using the model described below, coupled with the material parameters summarized in Table I, we computed the impact of

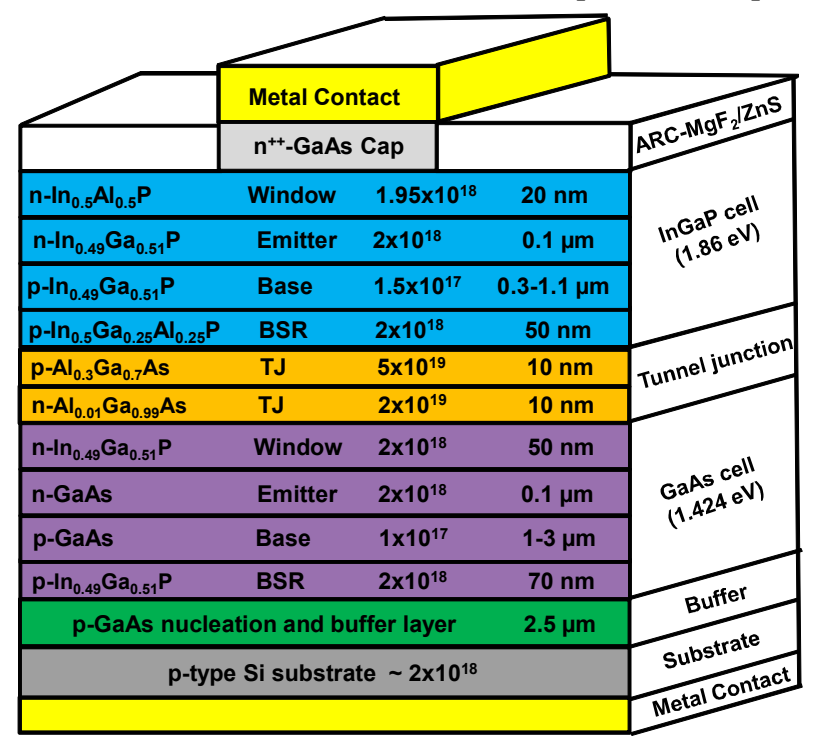

Fig. 1. Schematic depiction of $2 \mathrm{~J} \mathrm{InGaP} / \mathrm{GaAs}$ solar cell on $\mathrm{Si}$. 
TABLE I

GaAs AND InGaP MATERIAL AND TRANSPORT PARAMETERS

\begin{tabular}{|c|c|c|}
\hline \multirow[t]{2}{*}{ Parameter } & \multicolumn{2}{|c|}{ Value } \\
\hline & GaAs Subcell & InGaP Subcell \\
\hline Band-gap $\left(E_{g}\right)$ & $1.424 \mathrm{eV}$ & $1.86 \mathrm{eV}$ \\
\hline Minority electron mobility $\left(\mu_{\mathrm{e}}\right)$ & $3088.8 \mathrm{~cm}^{2} / \mathrm{Vs}$ & $1074 \mathrm{~cm}^{2} / \mathrm{Vs}[14]$ \\
\hline Minority hole mobility $\left(\mu_{\mathrm{h}}\right)$ & $100 \mathrm{~cm}^{2} / \mathrm{Vs}[11]$ & $40 \mathrm{~cm}^{2} / \mathrm{Vs}[14]$ \\
\hline Electron diffusion coefficient $\left(D_{n}\right)$ at $300 \mathrm{~K}$ & $80 \mathrm{~cm}^{2} / \mathrm{s}[12]$ & $27.816 \mathrm{~cm}^{2} / \mathrm{s}$ \\
\hline Hole diffusion coefficient $\left(\mathrm{D}_{\mathrm{p}}\right)$ at $300 \mathrm{~K}$ & $2.59 \mathrm{~cm}^{2} / \mathrm{s}$ & $1.036 \mathrm{~cm}^{2} / \mathrm{s}$ \\
\hline Peak minority electron life-time $\left(\tau_{n}^{\circ}\right)$ & $20 \mathrm{~ns}[7],[13]$ & $10 \mathrm{~ns}[15]$ \\
\hline Effective minority electron life-time $\left(\tau_{n}\right)$ & $\mathrm{f}\left(\tau_{\mathrm{TDD}}\right)$ & $\mathrm{f}\left(\tau_{\mathrm{TDD}}\right)$ \\
\hline Minority hole life-time $\left(\tau_{p}^{\circ}\right)$ & $2.5 \mathrm{~ns}$ & $1 \mathrm{~ns}$ \\
\hline
\end{tabular}

of TDD on the minority carrier base lifetime. This variation in this lifetime with increasing TDD, along with the material parameters incorporated from Table I, was used to model the impact of TDD on the photovoltaic performance of the $2 \mathrm{~J}$ InGaP/GaAs cells on Si using finite element analysis [10].

Minority carrier lifetime is one of the most important figureof-merit for metamorphic cell design. Defects and dislocations which are generated at the III-V/Si hetero-interface may serve as recombination centers and impede the minority carrier lifetime and hence their diffusion length. This degradation in lifetime may significantly impede the cell performance [4]-[6]. The effective minority carrier lifetime $\left(\tau_{n}\right.$ or $\left.\tau_{p}\right)$ in a latticemismatched system varies as a function of TDD ( $\left.\mathrm{f}\left(\tau_{\mathrm{TDD}}\right)\right)[7]$, [16] and can be expressed as,

$$
\frac{1}{\tau_{n, p}}=\frac{1}{\tau_{n, p}^{0}}+\frac{1}{\tau_{T D D}}
$$

where $\tau_{\mathrm{p}}^{\circ}$ and $\tau_{\mathrm{n}}^{\circ}$ are the minority carrier lifetime for a dislocation free material. The $\tau_{\mathrm{TDD}}$ is the minority carrier lifetime associated with the recombination at dislocation which can be expressed as,

$$
\tau_{T D D}=\frac{4}{\pi^{3}(T D D) D}
$$

where $\mathrm{D}$ is the minority carrier diffusion coefficient and TDD is the threading dislocation density in $\mathrm{cm}^{-2}$.

The impact of TDD on minority carrier base lifetime in GaAs and InGaP cell is shown in Fig. 2. The effective lifetimes in $\mathrm{p}$-GaAs $\left(\mathrm{N}_{\mathrm{A}}=1 \times 10^{17} \mathrm{~cm}^{-3}\right)$ and $\mathrm{p}$-InGaP $\left(\mathrm{N}_{\mathrm{A}}=1.5 \times 10^{17} \mathrm{~cm}^{-3}\right)$ were calculated using (1) and (2) with the parameters from Table I. The experimental lifetime values for p-GaAs (red) [13] and p-InGaP (green) [19] are included in this figure, indicating an excellent agreement between the model and experiment. It can be noted that for TDD higher than $\sim 10^{4} \mathrm{~cm}^{-2}$ in GaAs, the lifetime significantly degraded as minority electrons get recombined due to the high TDD. The onset of degradation in minority carrier lifetime began at a higher TDD $\left(\sim 10^{5} \mathrm{~cm}^{-2}\right)$ in InGaP cell compared to GaAs cell due to the lower electron diffusion coefficient in InGaP.

In a solar cell, the minority carriers that are generated in the thick base, far from the depletion region, need to have high lifetime to reach the junction before being recombined. Hence, the variation of minority electron lifetime in the $\mathrm{p}-\mathrm{GaAs}$ and $\mathrm{p}$ InGaP base had significant impact on the cell performance. On the other hand, minority holes generated in the thin n-type emitter had to travel much shorter lengths to reach the junction. Hence, minority hole lifetime was considered to be constant. The surface recombination velocity $(\mathrm{SRV})$ was set to $10^{4} \mathrm{~cm} / \mathrm{s}$ for both holes $\left(\mathrm{S}_{\mathrm{p}}\right)$ and electrons $\left(\mathrm{S}_{\mathrm{n}}\right)$ at $\operatorname{InGaP}$ base/back reflector interface and emitter/window interface. The corresponding $S_{n}$ and $S_{p}$ values were set to $10^{6} \mathrm{~cm} / \mathrm{s}$ at both the interfaces in the GaAs subcell. In our model, the mobility of minority carriers was assumed to be independent of TDD [16]. Also, the band-gap narrowing effect and the shadowing effect were not included in our model. Hence, the analysis discussed in this paper provides an upper bound for the modeled cell results.

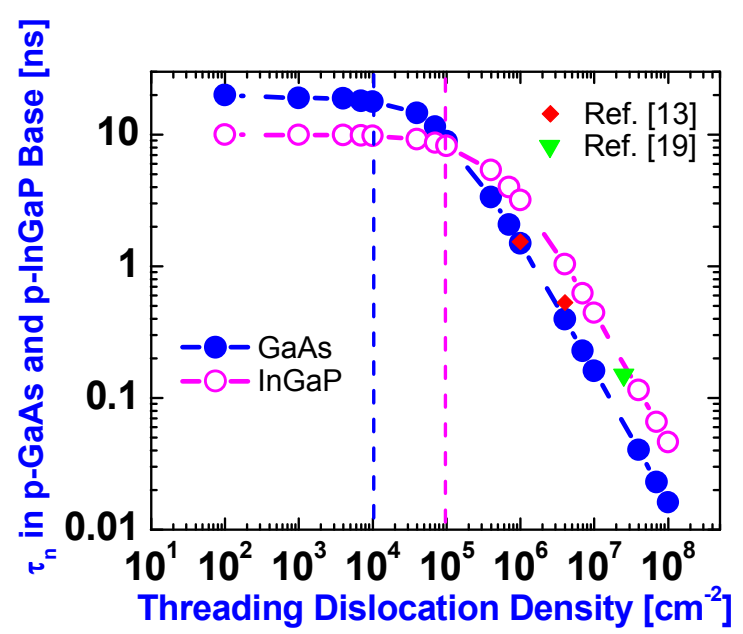

Fig. 2. Correlation of threading dislocation density on minority electron lifetime in $\mathrm{p}-\mathrm{GaAs}$ and $\mathrm{p}$-InGaP base. 
We calibrated our model with the $2 \mathrm{~J}$ InGaP/GaAs cell structure in [17], [18]. A $\tau_{\mathrm{n}}$ of $5.2 \mathrm{~ns}$ was used as reported [17]. We determined that this lifetime corresponds to a TDD of $\sim 4 \times 10^{5} \mathrm{~cm}^{-2}$ as shown in Fig. 2. Since, the value of $\tau_{\mathrm{n}}$ was not provided for the $\mathrm{p}-\mathrm{GaAs}$, a $\tau_{\mathrm{n}}$ of $3.3 \mathrm{~ns}$ was considered as calculated in Fig. 2. The simulation results are compared to the experimental results in Table II. Overall, simulated and the experimental values presented in Table II are in agreement, thus validating our model and the parameters utilized in this simulation study.

TABLE II

MODEL CALIBRATION WITH 2J InGaP/GaAs EXPERIMENTAL DATA

\begin{tabular}{lcccc}
\hline \hline & $\begin{array}{c}\mathrm{V}_{\mathrm{oc}} \\
(\mathrm{V})\end{array}$ & $\begin{array}{c}\mathrm{J}_{\mathrm{sc}} \\
\left(\mathrm{mA} / \mathrm{cm}^{2}\right)\end{array}$ & $\begin{array}{c}\mathrm{FF} \\
(\%)\end{array}$ & $\begin{array}{c}\text { Efficiency } \\
(\%)\end{array}$ \\
\hline Experiment [17] & 2.48 & 14.22 & 85.6 & 30.28 \\
Simulation & 2.41 & 13.85 & 88.9 & 29.80 \\
& & & & \\
Experiment [18] & 2.52 & 12.70 & 85.00 & 27.20 \\
Simulation & 2.58 & 12.53 & 85.19 & 27.64 \\
& & & & \\
\hline \hline
\end{tabular}

\section{RESULTS AND DISCUSSIONS}

This section is divided into two subsections. In the subsection A, the impact of threading dislocation density on the performance of $2 \mathrm{~J} \mathrm{n}+/ \mathrm{p}$ InGaP/GaAs cell on $\mathrm{Si}$ is discussed. Subsection B describes our approach of realizing the current-matching condition between each subcell by tailoring the $2 \mathrm{~J} \mathrm{InGaP} / \mathrm{GaAs}$ cell design on $\mathrm{Si}$ at a realistic TDD of $10^{6} \mathrm{~cm}^{-2}$.

\section{A. 2J InGaP/GaAs Cell on Si}

For the analysis of metamorphic $2 \mathrm{~J}$ InGaP/GaAs cell on $\mathrm{Si}$, the base thicknesses in the GaAs and InGaP subcells were initially set to $2.5 \mu \mathrm{m}$ and $0.9 \mu \mathrm{m}$, respectively. The TDD was varied from $10^{5}$ to $10^{8} \mathrm{~cm}^{-2}$ and it was assumed that all the threading dislocations in GaAs bottom subcell propagated to the top InGaP subcell.

Voltage at maximum power point, $\mathrm{V}_{\mathrm{m}}$ and $\mathrm{V}_{\mathrm{oc}}$ were plotted as a function of increasing TDD in the $2 \mathrm{~J} \mathrm{InGaP} / \mathrm{GaAs}$ cell on $\mathrm{Si}$ as shown in Fig. 3(a). Both $\mathrm{V}_{\mathrm{oc}}$ and $\mathrm{V}_{\mathrm{m}}$ degraded with increasing TDD. The primary reason for the decrease in $V_{o c}$ at higher TDD was due to its strong dependence on the reverse saturation current density, $\mathrm{J}_{02}$, associated with depletion region recombination. The $\mathrm{V}_{\text {oc }}$ can be expressed as,

$$
V_{o c}=\left(\frac{n_{2} k T}{q}\right) \ln \left(\frac{J_{s c}}{J_{02}}\right)
$$

where $\mathrm{J}_{02}$ depends on the minority lifetime in the base, $\tau_{\text {base }}$ and can be expressed as,

$$
J_{02}=\frac{q n_{i} W_{D}}{2}\left(\frac{1}{\tau_{\text {base }}}\right)
$$

where $\mathrm{n}_{\mathrm{i}}$ is the intrinsic carrier concentration and $\mathrm{W}_{D}$ is the depletion layer width. At higher TDD, the value of $\mathrm{J}_{02}$ increased due to the reduction in the minority electron lifetime in the base, $\tau_{\text {base }}$. Thus, the increase in $\mathrm{J}_{02}$ led to significant degradation of both $\mathrm{V}_{\mathrm{oc}}$ and $\mathrm{V}_{\mathrm{m}}$ at higher TDD.

Current density at maximum power point, $\mathrm{J}_{\mathrm{m}}$ and $\mathrm{J}_{\mathrm{sc}}$ were plotted as a function of increase in TDD in Fig. 3(b). Beyond a TDD of $10^{6} \mathrm{~cm}^{-2}$, the simultaneous reduction in minority electron lifetime in $\mathrm{p}-\mathrm{GaAs}$ and $\mathrm{p}$-InGaP led to the degradation
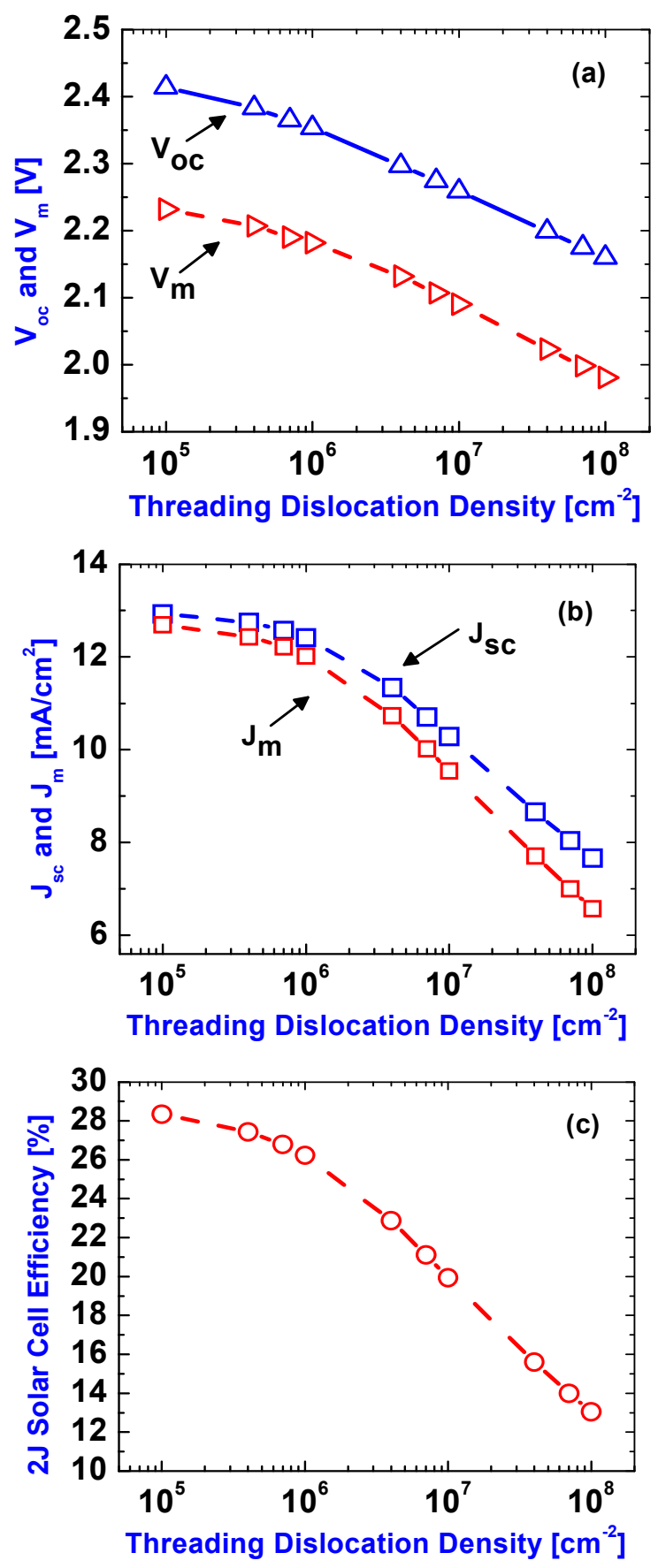

Fig. 3. Impact of threading dislocation density variation on $2 \mathrm{~J}$ InGaP/GaAs cell performance parameters: (a) $\mathrm{V}_{\mathrm{oc}}$ and $\mathrm{V}_{\mathrm{m}}$, (b) $\mathrm{J}_{\mathrm{sc}}$ and $\mathrm{J}_{\mathrm{m}}$ and (c) $\eta$ at AM1.5G. 
in $\mathrm{J}_{\mathrm{sc}}$. From a TDD of $10^{5}$ to $10^{8} \mathrm{~cm}^{-2}$, the degradation in $\mathrm{J}_{\mathrm{m}}$ was found to be greater than the degradation in $\mathrm{J}_{\mathrm{sc}}$. Furthermore; the onset of degradation in $\mathrm{J}_{\mathrm{sc}}$ began at higher TDD compared to $\mathrm{V}_{\mathrm{oc}}$ in the $2 \mathrm{~J}$ cell. Thus, $\mathrm{J}_{\mathrm{sc}}$ was found to be more tolerant to TDD compared to $\mathrm{V}_{\mathrm{oc}}$, consistent with prior work [9].

Even at a TDD of $10^{7} \mathrm{~cm}^{-2}\left(\tau_{\mathrm{n}}=0.44 \mathrm{~ns}\right)$, the electron diffusion length in $\mathrm{p}$-InGaP base was sufficient to travel the $0.9 \mu \mathrm{m}$ thick base. However, we observed that the onset of degradation in the $\mathrm{J}_{\mathrm{sc}}$ began at a lower TDD of $\sim 10^{6} \mathrm{~cm}^{-2}$ instead at a TDD of $10^{7} \mathrm{~cm}^{-2}$ (Fig. 2). This was attributed to the earlier onset of degradation in the minority electron lifetime in $\mathrm{p}$-GaAs compared to the $\mathrm{p}-\mathrm{InGaP}$. Hence, the bottom GaAs subcell limited the overall $\mathrm{J}_{\mathrm{sc}}$ in the $2 \mathrm{~J}$ cell configuration.

Fig. 3(c) shows the degradation of efficiency in 2J $\mathrm{InGaP} / \mathrm{GaAs}$ cell on $\mathrm{Si}$ as a function of increasing TDD. At a TDD of $10^{6} \mathrm{~cm}^{-2}$ in the $2 \mathrm{~J}$ structure, the corresponding $2 \mathrm{~J}$ cell efficiency was $26.22 \%$ with a minority electron lifetime of $1.49 \mathrm{~ns}$ and $3.17 \mathrm{~ns}$ in the GaAs and InGaP base, respectively. Above a TDD of $10^{7} \mathrm{~cm}^{-2}$, the $2 \mathrm{~J} \mathrm{InGaP/GaAs} \mathrm{cell} \mathrm{efficiency}$ degraded to that of $1 \mathrm{~J}$ GaAs cell efficiency at the same TDD, thus making the contribution of the top InGaP cell redundant. Therefore, it becomes extremely important to optimize the metamorphic $2 \mathrm{~J}$ cell structure on $\mathrm{Si}$ by carefully engineering the device structure, taking into account the detrimental impact the TDD may have on the cell performance.

\section{B. Current-matching in $2 \mathrm{~J}$ InGaP/GaAs Cell on Si}

In a multijunction cell, one of the most important design criteria is to achieve the current-matching between the subcells. Current-matching enables to extract the best performance from a multijunction cell. The subcell providing the least photocurrent limits the overall current in a multjijunction configuration. In our design, the subcells were not current-matched with the bottom GaAs subcell limiting the overall $\mathrm{J}_{\mathrm{sc}}$ in the $2 \mathrm{~J}$ configuration. Therefore, our tandem cell

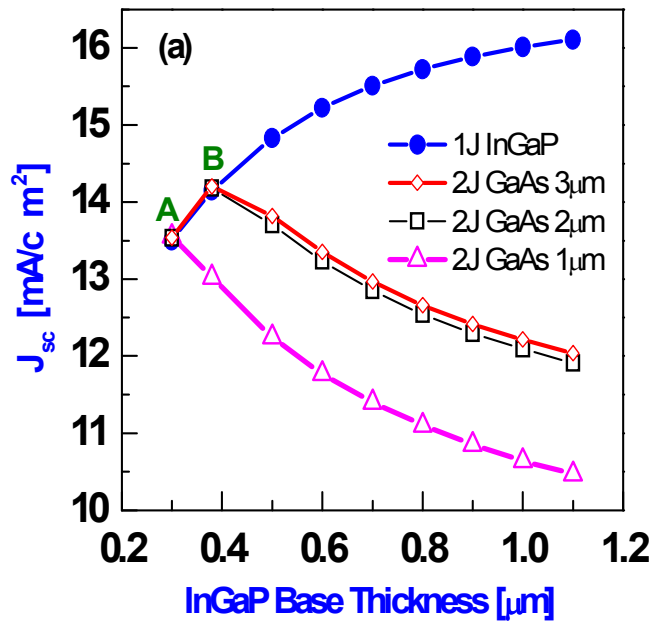

required appropriate design changes to achieve the currentmatching condition between the subcells. We varied the base thicknesses of both the GaAs and the InGaP subcells at an experimentally realistic TDD of $10^{6} \mathrm{~cm}^{-2}$ [20] to achieve the current-matching condition. At this TDD, the minority electron lifetime was calculated to be $1.494 \mathrm{~ns}$ and $3.171 \mathrm{~ns}$ in the pGaAs and the p-InGaP base, respectively.

We first varied the thickness of p-InGaP base from $0.3 \mu \mathrm{m}$ to $1.1 \mu \mathrm{m}$ in a $1 \mathrm{~J}$ InGaP cell configuration as shown by the blue curve in Fig. 4(a). Then, in the $2 \mathrm{~J}$ cell configuration, the InGaP base thickness was again varied over the same range with the GaAs base thickness set to $1 \mu \mathrm{m}$ (pink curve) as shown in Fig. 4(a). The same procedure was repeated for the GaAs base thickness of $2 \mu \mathrm{m}$ (black line) and $3 \mu \mathrm{m}$ (red line). It can be seen that thinning the base thickness in $1 \mathrm{~J}$ InGaP cell lowered the extracted $\mathrm{J}_{\mathrm{sc}}$ as the absorption depth was lowered. Interestingly, thinning the top InGaP cell in $2 \mathrm{~J}$ configuration allowed more photons to reach the bottom GaAs cell, increasing the $\mathrm{J}_{\mathrm{sc}}$ contribution from the bottom subcell. This led to an overall increase of $\mathrm{J}_{\mathrm{sc}}$ in the $2 \mathrm{~J}$ configuration as the bottom GaAs subcell limited the $\mathrm{J}_{\mathrm{sc}}$ in the $2 \mathrm{~J}$ configuration.

Utilizing the method discussed above, the current-matching condition was realized at points $A$ and point $B$ as shown in Fig. 4(a). The J-V characteristics of the $2 \mathrm{~J}$ cell and the individual subcells corresponding to the point $\mathrm{B}$ were plotted in Fig. 4(b). At point $\mathrm{B}$, the $2 \mathrm{~J}$ cell exhibited a conversion efficiency of $29.62 \%$ with a $2 \mu \mathrm{m}$ and a $0.38 \mu \mathrm{m}$ thick GaAs and InGaP base, respectively. This efficiency was significantly higher than the $2 \mathrm{~J}$ cell efficiency prior to the current-matching at the same TDD of $10^{6} \mathrm{~cm}^{-2}$. The cell parameters extracted after achieving the current-matching condition at a TDD of $10^{6}$ $\mathrm{cm}^{-2}$ were summarized in Table III. These results illustrate that an efficiency of greater than $29 \%$ can be realized for a metamorphic $2 \mathrm{~J}$ InGaP/GaAs solar cell on Si even at a TDD of $10^{6} \mathrm{~cm}^{-2}$. To further verify the results from this simulation study, experimental work is underway.

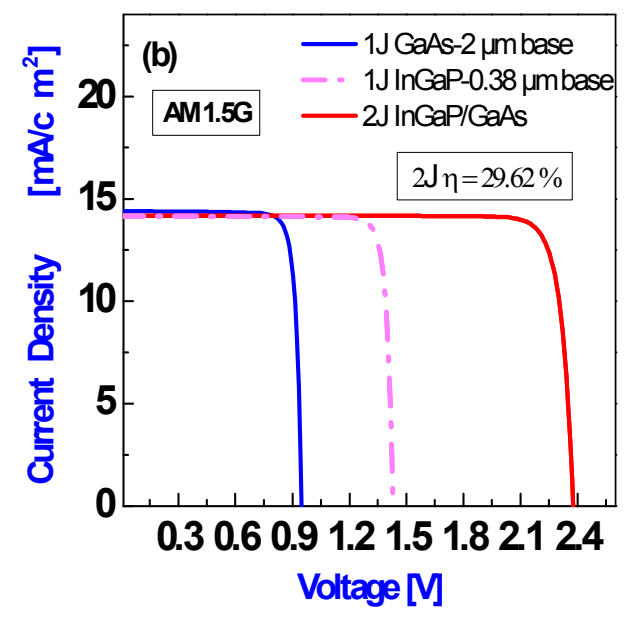

Fig. 4. a) Short-circuit current density as a function of top InGaP base thickness to optimize top and bottom cell base thicknesses for currentmatching, (b) Current-matched J-V characteristic in $2 \mathrm{~J} \mathrm{InGaP/GaAs} \mathrm{cell} \mathrm{at} \mathrm{AM} \mathrm{1.5G} \mathrm{in} \mathrm{for} \mathrm{current-matched} \mathrm{point} \mathrm{B} \mathrm{in} \mathrm{Fig.} 4$ (a). 
TABLE III

2J InGaP/GaAs CELL PARAMETERS AT AM 1.5G SPECTRUM

\begin{tabular}{ccccc}
$\begin{array}{c}2 \mathrm{~J} \text { cell }(\mathrm{InGaP} / \mathrm{GaAs} \\
\text { base thickness in } \\
\mu \mathrm{m})\end{array}$ & $\begin{array}{c}\mathrm{V}_{\mathrm{oc}} \\
(\mathrm{V})\end{array}$ & $\begin{array}{c}\mathrm{J}_{\mathrm{sc}} \\
\left(\mathrm{mA} / \mathrm{cm}^{2}\right)\end{array}$ & $\begin{array}{c}\mathrm{FF} \\
(\%)\end{array}$ & $\begin{array}{c}\text { Efficiency } \\
(\%)\end{array}$ \\
\hline $\begin{array}{c}\text { Non-optimized } \\
(0.9 / 2.5)\end{array}$ & 2.35 & 12.41 & 89.73 & 26.22 \\
$\begin{array}{c}\text { Current-matched } \\
(0.38 / 2)\end{array}$ & 2.37 & 14.18 & 88.22 & 29.62 \\
\hline \hline
\end{tabular}

\section{CONCLUSION}

We have investigated the impact of threading dislocation density on the photovoltaic performance of $2 \mathrm{~J} n+/ \mathrm{p}$ $\mathrm{InGaP} / \mathrm{GaAs}$ solar cell on Si at AM 1.5 spectrum. The analysis indicates that a $2 \mathrm{~J} \mathrm{InGaP} / \mathrm{GaAs}$ cell on $\mathrm{Si}$ exhibited a theoretical conversion efficiency of $26.22 \%$ with a $2.5 \mu \mathrm{m}$ and a $0.9 \mu \mathrm{m}$ thick GaAs and InGaP base, respectively. The onset of degradation in $\mathrm{V}_{\mathrm{oc}}$ began at a lower TDD than in $\mathrm{J}_{\mathrm{sc}}$, indicating that $\mathrm{V}_{\text {oc }}$ was more sensitive to the threading dislocations.

The design of the 2J InGaP/GaAs cell on Si was optimized taking into account a realistic TDD of $10^{6} \mathrm{~cm}^{-2}$. By thinning the top InGaP cell from $0.9 \mu \mathrm{m}$ to $\sim 0.4 \mu \mathrm{m}$, the currentmatching condition between the subcells was realized. As a result of current matching, the efficiency of the optimized structure increased to $29.62 \%$. Thus, even in a latticemismatched $2 \mathrm{~J} \mathrm{InGaP} / \mathrm{GaAs}$ cell on Si with TDD of $10^{6} \mathrm{~cm}^{-2}$, a theoretical conversion efficiency of greater than $29 \%$ at AM1.5G spectrum was achieved by tailoring the cell design. Once experimentally realized, this III-V cell technology on $\mathrm{Si}$ would offer a new paradigm for the advancement of low cost III-V solar cells and foster innovative avenues for both space and terrestrial applications.

\section{ACKNOWLEDGEMENT}

We would like to acknowledge David M. Wilt at Air Force Research Laboratory for valuable technical discussions and the Institute for Critical Technology and Applied Sciences (ICTAS) at Virginia Tech for the funding support.

\section{REFERENCES}

[1] G. J. Bauhuis, et al., "Wafer reuse for repeated growth of III-V solar cells," Prog. Photovoltaics: Res. Appl., vol. 18, pp. 155$159,2010$.

[2] R. Tatavarti, et al., "InGaP/GaAs/InGaAs inverted metamorphic (IMM) solar cells on 4" epitaxial lifted off (ELO) wafers," in Proc. 35th IEEE Photovoltaic Spec. Conf., 2010, pp. 002125002128.

[3] J. F. Geisz, et al., "High-efficiency GaInP/GaAs/InGaAs triplejunction solar cells grown inverted with a metamorphic bottom junction," Appl. Phys. Lett., vol. 91, pp. 023502-023502-3, 2007.
[4] R. K. Ahrenkiel, et al, "Minority-Carrier Lifetime of GaAs on Silicon", J. Electrochem. Soc., vol. 137, pp. 996-1000, 1990.

[5] J. A. Carlin, S. A. Ringel, A. Fitzgerald, and M. Bulsara, "Highlifetime GaAs on Si using GeSi buffers and its potential for space photovoltaics," Solar Energy Mater. Solar Cells, vol. 66, pp. 621-630, 2001.

[6] S. M. Vernon, et al., "Experimental study of solar cell performance versus dislocation density," in 21st IEEE Photovoltaic Specialist Conference, 1990, pp. 211-216.

[7] M. Yamaguchi, C. Amano, and Y. Itoh, "Numerical-Analysis for high-efficiency GaAs solar-cells fabricated on Si substrate," J. Appl. Phys., vol. 66, pp. 915-919, 1989.

[8] C. L. Andre, et al., "Impact of dislocation densities on $n(+) / p$ and $\mathrm{p}(+) / \mathrm{n}$ junction GaAs diodes and solar cells on $\mathrm{SiGe}$ virtual substrates," J. Appl. Phys., vol. 98, pp. 014502-014502-5, 2005.

[9] J. C. Zolper and A. M. Barnett, "The effect of dislocations on the open-circuit voltage of gallium-arsenide solar-cells," IEEE Trans. Electron Devices, vol. 37, pp. 478-484, 1990.

[10] "APSYS, Advanced Physical Models of Semiconductor Devices" by Crosslight Software Inc., Burnaby, BC, Canada, ed.

[11] M. L. Lovejoy, M. R. Melloch, and M. S. Lundstrom, "Minority hole mobility in GaAs," in M.R. Brozel and G.E. Stillman (eds.), Properties of Gallium Arsenide, Data Review Series no. 16, London: INSPEC, 1996, pp. 123-130.

[12] M. S. Lundstrom, "Minority carrier transport in III-V semiconductors," in R.K. Willardson, A.C. Beer, and E.R. Weber (eds.), Minority Carrier in III-V Semiconductors: Physics and Applications, Semiconductors and Semimetals, vol. 39: Academic Press Inc., 1993, pp.193-258.

[13] C. L. Andre, et al., "Impact of dislocations on minority carrier electron and hole lifetimes in GaAs grown on metamorphic SiGe substrates," Appl. Phys. Lett., vol. 84, pp. 3447-3449, 2004.

[14] M. Y. Ghannam, J. Poortmans, J. F. Nijs, and R. P. Mertens, "Theoretical study of the impact of bulk and interface recombination on the performance of $\mathrm{GaInP} / \mathrm{GaAs} / \mathrm{Ge}$ triple junction tandem solar cells," in Proc. 3rd World Conf Photovoltaic Energy Convers., 2003, pp. 666-669.

[15] T. Takamoto, E. Ikeda, H. Kurita, and M. Ohmori, "Structural optimzation for single junction InGaP solar cell," Solar Energy Mater. Solar Cells, vol. 35, pp. 25-31, 1994.

[16] M. Yamaguchi and C. Amano, "Efficiency calculations of thinfilm GaAs solar-cells on Si substrates," J. Appl. Phys., vol. 58, pp. 3601-3606, 1985.

[17] T. Takamoto, E. Ikeda, H. Kurita, and M. Ohmori, "Over 30\% efficient InGaP/GaAs tandem solar cells," Appl. Phys. Lett., vol. 70, pp. 381-383, 1997.

[18] C. Algora, et al., "Lattice-Matched III--V Dual-Junction Solar Cells for Concentrations Around 1000 Suns," J. Sol Energ, vol. 129, pp. 336-339, 2007.

[19] M. J. Yang, et al., "Photoluminescence analysis of InGaP top cells for high-efficiency multi-junction solar cells," Solar Energy Mater. Solar Cells, vol. 45, pp. 331-339, 1997.

[20] Y. Takano, et al., "Reduction of threading dislocations by InGaAs interlayer in GaAs layers grown on Si substrates," Appl. Phys. Lett. , vol. 73, pp. 2917-2919, 1998. 